\title{
ОРГАНІЗАЦІЙНА ПСИХОЛОГІЯ
}

\section{МАНІПУЛЯТИВНА ПОВЕДІНКА У ПРОФЕСІЙНІЙ ДІЯЛЬНОСТІ ОФІСНИХ СПІВРОБІТНИКІВ}

\section{MANIPULATIVE BEHAVIOR IN THE PROFESSIONAL ACTIVITIES OF OFFICE STAFF}

\author{
Крупник Іван Романович \\ кандидат психологічних наук, \\ доцент кафредри загальної та соціальної психології \\ Херсонський державний університет \\ AZONT@meta.ua \\ ORCID 0000-0003-4092-9781
}

\author{
Ткаленко Наталія Вікторівна \\ практичний психолог \\ natala.tkalenko921@gmail.com \\ ORCID 0000-0001-8288-6121
}

\author{
Krupnyk Ivan Romanovych \\ Candidate of Psychological Sciences, \\ Associate Professorof the Department \\ of General and Social Psychology \\ Kherson State University \\ AZONT@meta.ua \\ ORCID 0000-0003-4092-9781
practical psychologist
natala.tkalenko921@gmail.com
ORCID 0000-0001-8288-6121 \\ Tkalenko Natalya Viktorivna
}

\footnotetext{
Мета. Висвітлення маніпулятивної поведінки у професійній діяльності офрісних працівників, які працюють у системі «людина-людина». Важливо також дослідити це явище у динаміщі, тому у обстежені задіяні респонденти різного віку.

Методи. Загальнотеоретичні: аналіз, синтез положень, що містяться у психологічній літературі з проблеми психології маніпуляцій, порівняння, узагальнення, інтерпретація та систематизація теоретичних та емпіричних досліджень; емпіричні: методика «Дослідження макіавеллізму особистості» (адаптація В. Знакова) для виявлення рівня схильності особистості до маніпулятивної поведінки.

Результати та висновки. Під час аналізу виявлено, що відсоткові частки за результатами проведеного опитування у двох вибірках значно відрізняються. Зокрема, високого рівня проявів маніпулятивної поведінки у вибіриі досліджуваних віком 20-25 років не виявлено. Окрім того, середній рівень із тенденцією до високого у цій віковій групі теж займає меншу частку. Особистість починає навчатись взаємодіяти, спілкуватись у новій для себе соціальній ролі та у новій для себе діяльності - трудовій. Молодий фрахівещь більше спостерігає, пристосовується, адаптується до нового середовища, ніж впливає на нього. Натомість, у вибірці досліджуваних 26-44 років - високий рівень виявлено у двадияти відсотків. Таким чином, маніпулювання як тип поведінки превалює у вибіриі респондентів віком 26-44 роки. Це свідчить про те, що більш старші за віком фрахівці переконані в тому, що при спілкуванні з іншими людьми ними можна і потрібно маніпулювати, вони мають навички та конкретні уміння маніпулювати. Результати дослідження показали, що доросліші респонденти більш схильні до маніпулятивної поведінки. Це пов'язане із тим, що доросліша людина має значний арсенал маніпулятивних прийомів, розуміється в тому де і як можна їх застосовувати, мають навички та конкретні уміння маніпулювати. Виявлені розбіжності у застосуванні маніпуляиій між респондентами різних вікових груп, дозволяють простежити динаміку формування міжособистісних відносин у колективах.

Ключові слова: маніпулятивний вплив, макіавеллізм, закономірності процесу маніпулювання, вікові особливості схильності до використання маніпуляцій.

Purposes. Coverage of manipulative behavior in the professional activities of office workers working in the "man-man". It is also important to study this phenomenon in dynamics, so the survey involved respondents of different ages.

Methods. General theoretical: analysis, synthesis of the provisions contained in the psychological literature on the psychology of manipulation, comparison, generalization, interpretation and systematization of theoretical and empirical research; Empirical: methodology "Study of Machiavellian personality" (adaptation. Symbolic), to identify the level of propensity of the individual to manipulative behavior. The goal of the method: identifying makovelski attitudes and beliefs of the subjects. Methods of mathematical statistics, in particular the Fisher angular transformation criterion, were also used.

Results and conclusions. The analysis revealed that the percentages of the survey results in the two samples differ significantly. In particular, a high level of manifestation of manipulative behavior in a sample of subjects aged 20-25 years was not revealed. In addition, the average level with a tendency to high in this age group also occupies a smaller proportion. The personality begins to learn to interact, to communicate in a new social role and in a new activity - labor. The young specialist observes, adapts, adapts to the new environment more than influences him. But, in the sample of the studied 26-44 years - a high level was found in twenty percent. Thus, manipulation as a type of behavior prevails in the sample of respondents aged 26-44 years. This suggests that older specialists are convinced that when communicating with other people they can
} 
and should be manipulated, they have the skills and specific skills to manipulate. The results of the study showed that adult respondents are more prone to manipulative behavior. This is due to the fact that an adult has an impressive Arsenal of manipulative techniques, it is understood where and how they can be used, have the skills and specific skills to manipulate. The differences in the use of manipulations between respondents of different age groups, allow us to trace the dynamics of the formation of interpersonal relationships in teams.

Key words: manipulative influence, machiavellianism, the patterns of the handling process, age-related features of the tendency to use manipulation.

Прагнення до успішної самореалізації в жорстких умовах динамічного суспільства, що проявляється в схильності до маніпулювання - одна з характерних особливостей сучасної людини (Знаков, 2012; Татенко, 2003).

У результаті світового науково-технічного прогресу відбулися значні зміни у сфрері науки, техніки, виробництва і споживання, що, у свою чергу, позначилось на особливостях взаємодії людей - все більшої актуальності набуває проблема маніпуляції свідомістю людей. Високий рівень розвитку комунікативно-інформаційних засобів призводить до інтенсивного руху інформаційних потоків. Маніпулювання свідомістю стає системним явищем, що охоплює всі сфери життя і проявляється в різноманітних формах. Маніпулювання свідомістю в сучасних умовах постає як системне явище, яке проявляється у багатьох видахі фрормах, і знаходить своє відображення в комплексі засобів маніпулятивного впливу. Людина, як суб'єкт соціальних відносин, намагається контролювати будь-яку ситуацію і тому у своїй професійній діяльності і особистому життівдається до різних механізмів маніпулювання (Кальниш, 2004; Матвієнко, 2001). Аналіз літератури вказує на те, що проблема маніпуляції як інструмента впливу поширена в сучасній діловій практиці. Широке використання маніпулятивного впливу, маніпулятивних засобів у діловій сфрері зазвичай переноситься на сферу дружби, неформальних міжособистісних стосунків, що призводить до руйнації довірливих зв'язків між людьми, що, в свою чергу, позначається на ефективності праці та успішності кожного фахівця.

Негативний вплив маніпуляції на міжособистісне спілкування та взаємодію людей підтверджує актуальність дослідження цього явища.

Теоретичне обґрунтування проблеми. Метою роботи $€$ висвітлення маніпулятивної поведінки у професійній діяльності офісних працівників, які працюють у системі «людина-людина». Важливо також дослідити схильність особистості до маніпуляцій у динаміці, тому необхідно задіяти у обстежені респондентів різного віку.

Для досягнення мети ми поставили перед собою виконання таких завдань:

1. Провести теоретичний аналіз проявів маніпулятивної поведінки у професійній діяльності;

2. Емпірично дослідити особливості маніпулятивної поведінки фахівців, які працюють у системі «людина-людина» різних вікових груп.

Маніпуляція - це прихований психологічний прийом, метою якого є змусити людину, всупереч її інтересам, виконати потрібні для маніпулятора дії.
Дослідники даного феномену поділялись на тих, хто вивчав маніпуляції масовою свідомістю і маніпуляції в міжособистісному спілкуванні. У рамках дослідження проблем міжособистісної маніпуляції було також виділено декілька підходів. Маніпуляція в міжособистісному спілкуванні розглядається у рамках:

1) психології впливу як один з видів впливу, направлений на спонукання співрозмовника до здійснення запланованих маніпулятором дій;

2) ціннісно-смислового підходу як монологічна форма міжособистісної взаємодії, в якій відбувається нівелювання (вимірювання) цінності іншого і самого спілкування як такого;

3) психології розуміння як ментальний конструкт суб'єктів взаємодії (Знаков, 2012).

Таким чином, доцільно надати визначення поняттю «маніпуляція», яке увібрало би те загальне, що об'єднує приведені вище дефрініції: маніпуляція це приховане управління адресатом з боку ініціатора, під час якого останній досягає своїх цілей, при цьому наносячи збитки адресату (Татенко, 2003).

Можна виділити певну суперечність по відношенню до маніпуляції. 3 одного боку, загальноприйнятим $є$ той факт, що це негативне явище. Але у працях, присвячених маніпуляції (Шейнов, 2010) можна виокремити і позитивну роль. Маніпуляція може бути використана і в інтересах того, ким маніпулюють. Наприклад, для того, щоб хто-небудь кинув пити, палити і т.д. Якщо дії ініціатора здійснюються в інтересах адресата, то це соціально прийнятне управління. Якщо ж приховане управління адресатом наносить збитки, то це маніпуляція (засуджується у суспільній свідомості).

3 точки зору В. Москаленко, міжособистісний вплив (маніпулювання) $є$ складним процесом дії однієї людини на іншу, в якому застосовуються різні способи, прийоми, техніки і засоби соціального тиску. Прямо чи опосередковано ці сили тиску мають на меті управляти емоціями інших людей, щоб зробити людину більш податливою до впливу.Вище зазначеним науковцем були виділені два головних види маніпуляцій: маніпуляція за допомогою вербальних засобів впливу; маніпуляція за допомогою невербальних засобів впливу (Москаленко, 2007).

Зпсихологічної точки зору, вважає В. Знаков, треба розрізняти маніпуляцію, усвідомлювану та неусвідомлювану самим маніпулятором (Знаков, 2002).

Дослідження маніпулятивної поведінки у руслі організаційної психології ставили питання про ефективність маніпуляцій в досягненні кар'єрних висот і здобутті та утриманні влади. Тобто розглядали, як 
правило, макіавеллістські риси особистості. У цих дослідженнях було виявлено зв'язок між частотою використання маніпуляцій з мотивацією досягнення, але в цілому картина неоднозначна. Так, наприклад, О. Садон стверджує, що професійна успішність фахівця залежить не лише від його здібностей, особистісних якостей, мотивації і цінностей, а й від сформованої ще під час навчання здібності вибудовувати стратегії і тактики гнучкої орієнтації у професійному середовищі (Шейнов, 2010).

В. Шейнов пропонує розділяти три види прихованого управління в залежності від моральності цілей ініціатора впливу: асертивне, коли при виграші як ініціатор, так і адресат впливу; альтруїстичне, коли виграш адресата може супроводжуватись поразкою самого ініціатора впливу; маніпулятивне (егоїстичне) - приховане управління в особистих цілях ініціатора, що не відповідають інтересам адресата впливу (Шейнов, 2010).

До теперішнього часу відсутній єдиний підхід до вивчення маніпулятивних технологій. Особливо не вивчені маніпулятивні технології в трудовому процесі. Проте виявлено, що маніпулювання у робочих відносинах має такі цілі та завдання: зробити іншого знаряддям виконання своїх намірів; перекласти на іншого частину своєї роботи;піти від особистої відповідальності, зокрема, переклавши ії на інших;самоствердитися (в тому числі - і за рахунок іншого); вирішити свої психологічні проблеми, в тому числі -внутрішньоособистісні конфлікти; надати взаємовідносинам бажаний вид (наприклад, встановити дистанцію, показати ступінь довіри і т.д.); отримати виграш в комфортності свого становища.

В результаті досліджень було доведено, що не тільки керівники керують підлеглими, а й підлеглі керівниками. Цілі у них майже збігаються, однак є дві суттєві відмінності:

1. Приховане управління - це єдиний спосіб для підлеглих управляти керівниками.

2. Керуючи своїм начальником, підлеглий діє обережніше, оскільки усвідомлення керівником того, що ним керують, може дорого обійтися підлеглому.

Приховане управління підлеглими здійснюється керівником за наступними напрямками: 1) нейтралізація його недоліків як керівника (недостатній професіоналізм, негативні риси характеру, прогалини в освіті, недостатній розвиток культури); 2) досягнення особистого зиску ініціатора впливу не на шкоду роботі і керівнику; 3) отримання особистої вигоди на шкоду роботі, колегам, керівнику. Останній випадок і є маніпуляцією.

Отже, маніпуляція - це приховане управління адресатом з боку ініціатора, під час якого останній досягає своїх цілей, при цьому наносячи збитки адресату. Маніпуляція є досить часто використовуваним засобом впливу керівника на підлеглих і навпаки.

Серед індивідуальних джерел виникнення у особистості схильності до маніпуляції Є. Доценко визначає як мінімум два: невротичні потреби та інерційні процеси (характерологічні особливості, звички і т. д.) (Доценко, 2003).

Аналіз наукових публікацій, присвячених дослідженню схильності до маніпуляції, дозволяє зазначити, що у психологічному портреті макіавелліста існують такі штрихи як домінантність, агресивність і асоціальність. Окрім того виявлено, що в залежності від віку, люди здатні по-різному сприймати й застосовувати маніпулятивні техніки. Чоловіки й жінки старшого віку мають більш низький рівень макіавеллізму, ніж юнаки й дівчата. Це, в першу чергу, пов'язано з тим, що макіавеллізм проявляється в маніпулятивних тактиках, спрямованих на досягнення суб'єктом конкретних кар'єрних цілей. Такі тактики для молодих людей здаються ефективними, адже застосовуються в короткострокових контактах, спілкуванні, що не припускає встановлення близьких відносин. У старшому ж віці у людей скорочується кількість таких соціальних ситуацій та звужується коло близьких знайомих, якими очевидно небажано маніпулювати» (Гуменюк, 2003).

На думку М. Обозова, юнаки мають стійку усвідомлену установку на збагачення й життєвий успіх, високий рівень бажань, зокрема, бажання отримати вигоду (Єрмакова, 2014). У ситуаціях, що вимагають морального вибору, молоді люди прагнуть мати «престижні» моральні якості, які описують людину як таку, що «вміє жити» (хитрощі, спритність), а також сумніваються в обґрунтованості більшості загальноприйнятих норм. У свою чергу, Є. Доценко наголошує, що юнакам властиве прагнення перекладати провину за власні недоліки на оточуючих (Доценко, 2003).

Е. Еріксон пояснює таку відмінність між молодими та зрілими людьми у поглядах і тактиках маніпулювання особливостями періодизації особистісного розвитку (Еріксон, 2006). Період ранньої зрілості (20-25 років) полягає в зайвій зануреності у себе чи в униканні міжособистісних відносин. Занурені в себе люди можуть вступати в зовсім формальну особистісну взаємодію (роботодавець - працівник) і встановлювати поверхневі контакти. Їм також властиво займати позицію відчуженості і не зацікавленості у відносинах, що є характерним для вираженого типу макіавеллістської особистості. Період середньої зрілості (26-60 років) відрізняється появою почуття самореалізації в людини, що зв'язане з досягненнями його нащадків. Тому на зміну маніпулятивним технікам приходить гуманні та соціально бажані форми взаємодії.

Методологія та методи. Для розв'язання поставлених завдань були використані методи:

- загальнотеоретичні: аналіз, синтез положень, що містяться у психологічній літературі з проблеми, що вивчається, порівняння, узагальнення, інтерпретація та систематизація теоретичних та емпіричних досліджень;

- емпіричні: психодіагностичні методи - методика «Дослідження макіавеллізму особистості» (адаптація В. Знакова), для виявлення рівня схильності особистості до маніпулятивної поведінки. Мета методики: виявлення макіавеллістських установок 
і переконань випробовуваних. Вимір рівня макіавеллізму особистості, тобто властивості особистості, що включає в себе цинізм, відчуженість, емоційну холодність, використання інших в своїх цілях. Тобто, дослідження макіавеллізму дозволяє визначити схильність людини до маніпулятивної поведінки. Високий показник макіавеллізму, отриманий в результаті підрахунку, свідчить про те, що макіавеллізм, як властивість особистості, в повсякденному житті проявляється в маніпулятивних тактиках, спрямованих на досягнення суб'єктом конкретних кар'єрних цілей.

- методи математичної статистики: описова статистика - для визначення середніх, мінімальних показників у групі; порівняльний аналіз (критерій кутового перетворення Фішера) для оцінки відмінності між відсотковими частками двох вибірок;

Метою емпіричної частини є дослідження схильності до використання маніпулятивної поведінки у офрісних співробітників 20-25 років (рання зрілість) та 25-44 років (середній вік). Дослідження було проведено на базі ТОВ «Везом». Загальна кількість респондентів 40 осіб. 3 них: чоловіки - 24, жінки - 16. Спираючись на періодизацію розвитку особистості, розроблену Е. Еріксоном, аналіз та порівняння результатів показників було проведено між двома вибірками: 20-25 років (рання зрілість) та 25-44 роки (середній вік). Вибірку 20-25 років склали 20 осіб: чоловіки - 11, жінки - 9. До вибірки 26-44 роки увійшли 20 респондентів, з них: 13 - чоловіки, 7 - жінки. Превалююча професійна діяльність оптантів - розробка, просування сайтів та пошук клієнтів.

Результати та дискусії. Аналіз та інтерпретація результатів тесту «Методика дослідження макіавеллізму особистості» (адаптація В. Знакова).

Від загальної кількості досліджуваних респонденти віком 20-25 років, показники за методиками у 8 респондентів відповідають середньому показнику з тенденцією до низького (таким людям притаманні чесність та надійність, вони більш відкриті у спілкуванні), 7 осіб мають середній показник 3 тенденцією до високого і 5 осіб - низький рівень макіавеллізму (схильності до маніпулятивної поведінки). Високого рівня показника маніпулятивного ставлення особистості до інших людей не має жоден оптант даної вибірки (див. рис. 1).

У відсотковому відношенні, низький рівень макіавеллізму (від 61,75 балів і нижче) має 25\% досліджуваних, середній показник з тенденцією до високого мають 35\% досліджуваних (від 73,78 до 85,81 балів) і 40\% мають середній показник з тенденцією до низького (73,78-61,75 балів).

Низький рівень макіавеллізму вказує на те, що респонденти мають такі особливості: вони легко піддаються впливу, чесні, сентиментальні і надійні. Характерні риси - це невміння відмовляти в необґрунтованому проханні, вимагати, відстоювати свої права, виражати позитивні й негативні емоції у колективі. На нашу думку, такі особливості пов'язані з тим, що у віці 20-25 років лише відбувається оволодіння обраною професією. Людина стверджує себе в ній, здобуває професійну майстерність. Особистість починає навчатись взаємодіяти, спілкуватись у новій для себе соціальній ролі та у новій для себе діяльності - трудовій. В цей час лише розвиваються необхідні спеціальні особистісні та функціональні якості: організаторські здібності, ініціативність, винахідливість, чіткість і акуратність, швидкість реакції. Якщо це новий колектив або перша робота, то при спілкуванні та взаємодії можна спостерігати сором'язливість, страх перед новим, скутість висловлювань, залежність від думки оточуючих. Молодий фахівець більше спостерігає, пристосовується, адаптується до нового середовища.

Результати досліджуваних, які мають на час обстеження 26-44 роки. Низьке значення макіавеллізму мають 10\% досліджуваних (2 особи), по 20\% досліджуваних (4 особи) мають середнє значення з тенденцією до низького та високий рівень макіавеллізму і 50\% досліджуваних (10 респондентів) мають середній рівень макіавеллізму з тенденцією до високого (див. рис. 2).

Під час аналізу отриманих даних виявлено, що відсоткові частки за результатами проведеного опитування у двох вибірках значно відрізняються. Високого рівня макіавеллізму у вибірці досліджуваних віком

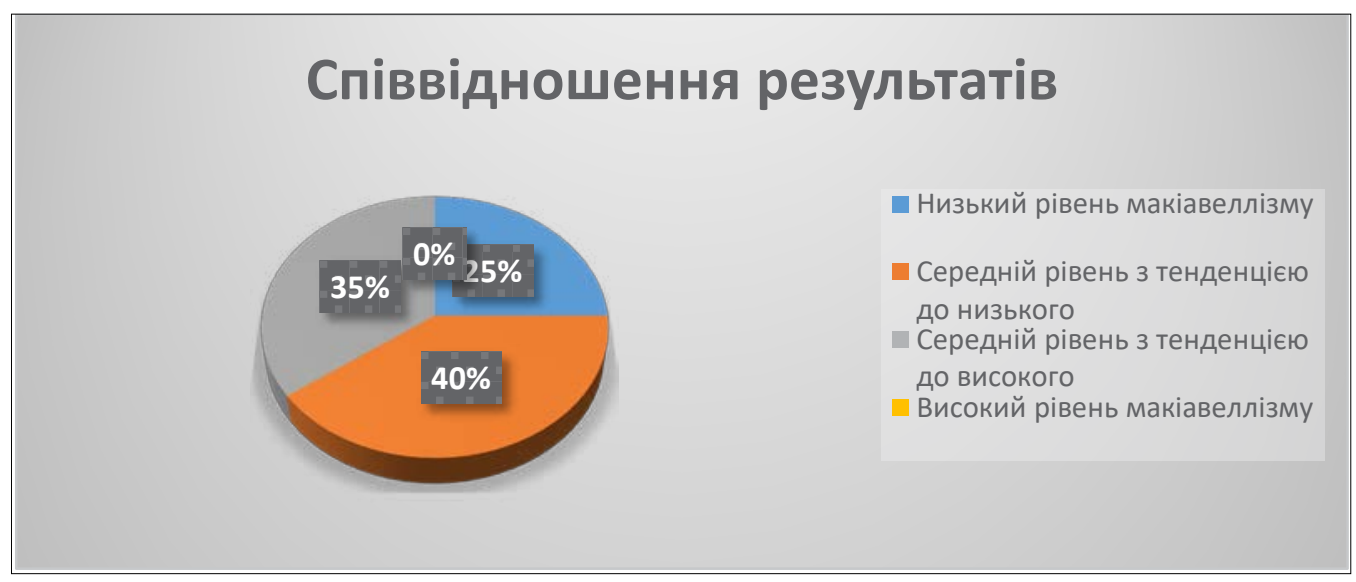

Рис. 1. Результати проведеного опитування серед офісних співробітників віком 20-25 років 
20-25 років не виявлено. Натомість, у вибірці досліджуваних 26-44 роки - виявлено у 4 респондентів (20\%).

Враховуючи, що у вибірці молодших респондентів середній рівень із тенденцією до високого теж займає меншу частку, а високих показників немає взагалі, ми можемо стверджувати - маніпулювання як тип поведінки превалює у вибірці респондентів віком 26-44 роки (див. табл. 1).

Таким чином доведено, що вибірка досліджуваних старших за віком частіше зустрічаються з феноменом маніпулювання. А отже, частіше його і застосовує у профресійному та повсякденному житті.У профеесійній діяльності - це небажання нести відповідальність за свою роботу, бажання отримувати вигоду за допомогою чужих старань. Низький рівень схильності до маніпуляції у вибірці оптантів віком 20-25 років дорівнює $25 \%$, що на $15 \%$ більше, ніж у вибірки, респонденти якої на час дослідження мають від 26 до 44 років. За підрахунками середнього рівня з тенденцією до високого та низького виявлено: у вибірці «рання зрілість» середній рівень 3 тенденцією до низького мають $40 \%$ респондентів і $35 \%$ - рівень 3 тенденцією до високого. Середній рівень з тенденцією до низького у вибірці «середній вік» мають 20\% та до високого $50 \%$ усіх респондентів. Дані порівняння свідчать про те, що молодші за віком працівники мають меншу схильність до маніпулювання та менше застосовують маніпулятивні тактики для досягнення професійних та індивідуальних цілей на відміну від більш дорослих працівників. Це, на нашу думку, пов'язано з віковими особливостями та досвідом застосування маніпуляцій по відношенню один до одного. Тобто, досліджувані віком 26-44 роки більш обізнані та досвідченні в застосуванні маніпуляцій, ніж досліджувані віком від 20 до 25 років.Це свідчить про те, що більш старші за віком фахівці переконані в тому, що при спілкуванні з іншими людьми ними можна і потрібно маніпулювати, вони мають навички та конкретні уміння маніпулювати. Ближче до 30 років головними стають чіткі чинники мотивації праці: внутрішні задоволення від самого процесу роботи і значимість одержуваного результату, зовнішні - заробітна плата, матеріальне заохочення, визнання в трудовому колективі і в цілому в професійному співтоваристві. Людина вже реально оцінює свої можливості, коригує життєві цінності та поведінку. Вона стає більш наполегливою, починає застосовувати методи впливу на інших співробітників з метою досягнення своїх цілей.

Висновки та перспективи подальших наукових розвідок. Результати дослідження показали, що доросліші респонденти мають більше схильності до маніпулятивної поведінки. Це може бути пов'язане із тим, що доросліша людинамає більший арсенал маніпулятивних тактик та прийомів, розуміється в тому де і як можна їх застосовувати, а з ким цього робити не потрібно. Тому часто досить складно виявити маніпулятора у організаційному процесі. Виявлені розбіжності у застосуванні маніпуляцій між респондентами різних вікових груп, дозволяють простежити динаміку формування міжособистісних відносин у колективах.

Перспективи подальших досліджень вбачаються у ґрунтовному дослідженні маніпулятивних тактик, що застосовуються у професійній діяльності для розробки навчальної програми протидії психологічним маніпуляціям для фрахівців, які працюють у системі «людина-людина». Результати дослідження особливостей маніпулятивної поведінки офісних співробітників різних вікових категорій можуть бути використані організаційними психологами, фрахівцями HR - відділів та безпосередньо керівництвом організацій.

\section{Співвідношення результатів}

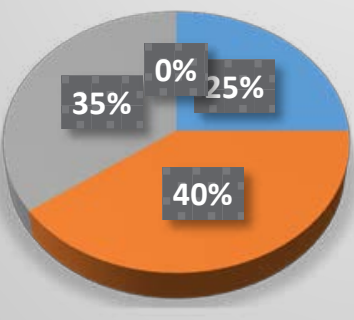

- Низький рівень макіавеллізму

— Середній рівень з тенденцією

до низького

Середній рівень з тенденцією

до високого

Високий рівень макіавеллізму

Рис. 2. Результати проведеного опитування серед офісних співробітників віком 26-44 роки

Значущі розбіжності між показниками макіавеллізму у різні вікові періоди

Таблиця 1

\begin{tabular}{|c|c|c|c|c|}
\hline $\begin{array}{c}\text { Маніпулятивна поведінка } \\
\text { (високий рівень) (\%) }\end{array}$ & $\begin{array}{c}\text { Респонденти віком } \\
\text { 20-25 років }\end{array}$ & $\begin{array}{c}\text { Респонденти віком } \\
\mathbf{2 6 - 4 4} \text { роки }\end{array}$ & Критерій Фішера & Рівень значимості \\
\hline $\begin{array}{c}\text { високий та з тенденцією } \\
\text { до високого рівні }\end{array}$ & 35 & 70 & 2,26 & P $\leq 0,05$ \\
\hline
\end{tabular}




\section{ЛITEPATУРА}

1. Гуменюк О. Маніпуляція як різновид психологічного впливу. Практична психологія та соціальна робота. 2003. № 5. C. 23-26

2. Доценко Е. Психология манипуляции: феномены, механизмы и защита. СПб., 2003. 304 с.

3. Єрмакова Н. Психологічні особливості проявів маніпулятивної поведінки в юнацькому віці. Науковий вісник Херсонського державного університету. 2014. Випуск 1. С. 164-171.

4. Знаков В.В. Макиавеллизм, манипулятивное поведение и взаимопонимание в межличностном общении. Вопросы психологии. 2012. № 6. С. 45-54.

5. Кальниш В., Кальниш Ю. Роль деяких специфічних психологічно-особистісних якостей у професійній кар'єрі державного службовця: мак'явелізм. Вісник Національної академії державного управління при Президентові України. 2004. № 1. С. 77-85.

6. Крупник І.Р. Психолого-педагогічна програма «Співпраця»: досвід впровадження Науковий вісник Херсонського державного університету. Серія: Психологічні науки. 2017. Вип.1. Том 2. С. 82-86.

7. Матвієнко В.Я. Соціальні технології. Київ, 2001. 446 с.

8. Москаленко В. Психологія соціального впливу: навч. посіб. Київ, 2007. 448 с.

9. Татенко В. Соціально-психологічні механізми впливу людини на людину. Соціальна психологія. 2003. № 1. С. 60-72.

10. Шейнов В. Скрытое управление человеком. Минск, 2010. 848 с.

11. Эриксон Э. Идентичность: юность и кризис / пер. с англ. общ. ред. А. Толстых. Москва, 2006. 352 с.

\section{REFERENCES:}

1. Dotsenko, E. (2003). Psikhologiia manipuliatsii: fenomeny, mekhanizmy i zashchita [Psychology of manipulation: phenomena, mechanisms and protection]. SPb., 2003. 304[in Russian].

2. Erikson E. (2006) Identichnost : iunost i krizis [Identity: Youth and Crisis] / per. s angl. obshch. red. A. Tolstykh. Moskva. 352 [in Russian].

3. Humeniuk, O. (2003). Manipuliatsiia yak riznovyd psykholohichnoho vplyvu [Manipulation as a kind of psychological influence] Praktychna psykholohiia ta sotsialna robota - Practical psychology and social work, 5. 23-26 [in Ukrainian].

4. lermakova N. (2014) Psykholohichni osoblyvosti proiaviv manipuliatyvnoi povedinky v yunatskomu vitsi. [Psychological features of manipulative behavior in adolescence]. Naukovyi visnyk Khersonskoho derzhavnoho universytetu - Scientific Bulletin of Kherson State University. Series: Psychological Sciences, 1. 164-71 [in Ukrainian].

5. Kalnysh V., Kalnysh Yu. (2004) Rol deiakykh spetsyfichnykh psykholohichno-osobystisnykh yakostei u profesiinii karieri derzhavnoho sluzhbovtsia: makiavelizm [The role of some specific psychological and personal qualities in a professional career civil servant: machiavellianism] Visnyk Natsionalnoi akademii derzhavnoho upravlinnia pry Prezydentovi Ukrainy Bulletin of the National Academy of public administration under the President of Ukraine, 1. 77-85 [in Ukrainian].

6. Krupnyk I.R. (2017) Psykholoho-pedahohichna prohrama «Spivpratsia»: dosvid vprovadzhennia [Psycho-pedagogical program "cooperation": implementation experience] Naukovyi visnyk Khersonskoho derzhavnoho universytetu. Seriia: Psykholohichni nauky - Scientific Bulletin of Kherson State University. Series: Psychological Sciences, 1(2). 82-86 [in Ukrainian].

7. Matviienko V. (2001) Sotsialni tekhnolohii [Social technology]. Kyiv. [in Ukrainian].

8. Moskalenko V. (2007) Psykholohiia sotsialnoho vplyvu: navch. Posib [Psychology of social influence] Kyiv. [in Ukrainian].

9. Sheinov V. (2010) Skrytoe upravlenie chelovekom [The latent management of the person]. Minsk. [in Russian].

10. Tatenko V. (2003) Sotsialno-psykholohichni mekhanizmy vplyvu liudyny na liudynu. [Social and psychological mechanisms of human influence on a person] Sotsialna psykholohiia - Social psychology, 1. 60-72 [in Ukrainian].

11. Znakov V.V. (2012) Makiavellizm, manipuliativnoe povedenie i vzaimoponimanie v mezhlichnostnom obshchenii [Machiavellianism, manipulative behaviour and mutual understanding in interpersonal communication]. Voprosy psikhologii Question of psychology, 6. 45-54 [in Russian]. 